慶應義塾大学学術情報リポジトリ

Keio Associated Repository of Academic resouces

\begin{tabular}{|c|l|}
\hline Title & Effect of double bond on the surface properties of aqueous solutions of eicosapolyenoic acids \\
\hline Sub Title & \\
\hline Author & $\begin{array}{l}\text { 横山, 祥子(Yokoyama, Shoko) } \\
\text { 中垣, 正幸(Nakagaki, Masayuki) }\end{array}$ \\
\hline Publisher & 共立薬科大学 \\
\hline Publication year & 1993 \\
\hline Jtitle & $\begin{array}{l}\text { 共立薬科大学研究年報 (The annual report of the Kyoritsu College of } \\
\text { Pharmacy). No.38 (1993.) ,p.82-82 }\end{array}$ \\
\hline JaLC DOI & \\
\hline Abstract & \\
\hline Notes & 抄録 \\
\hline Genre & Technical Report \\
\hline URL & https://koara.lib.keio.ac.jp/xoonips/modules/xoonips/detail.php?koara_id=AN00062898-0000003 \\
& 8-0082 \\
\hline
\end{tabular}

慶應義塾大学学術情報リポジトリ(KOARA)に掲載されているコンテンツの著作権は、それぞれの著作者、学会または出版社/発行者に帰属し、その権利は著作権法によって 保護されています。引用にあたっては、著作権法を遵守してご利用ください。

The copyrights of content available on the KeiO Associated Repository of Academic resources (KOARA) belong to the respective authors, academic societies, or publishers/issuers, and these rights are protected by the Japanese Copyright Act. When quoting the content, please follow the Japanese copyright act. 
No. 38 (1993)

\title{
Effect of Double Bond on the Surface Properties of Aqueous Solutions of Eicosapolyenoic Acids*
}

\author{
Shoko Yokoyama and Masayuki NaKagakı** \\ 横山祥子, 中垣正幸**
}

Surface tensions of aqueous solution of eicosapolyenoic acids (EA) with $2 \sim 5$ double bonds were measured by use of a Du Nouy tensiometer at $\mathrm{pH} 7.80$ and $25^{\circ} \mathrm{C}$, and the effects of double bond on the surface properties of EA were investigated. The value of critical micelle concentration of EA increased twofold with increasing number of double bonds. The free energy for the adsorption per double bond at the air-water interface was estimated as $2.47 \mathrm{~kJ}$ (double bond) ${ }^{-1}$, and the negative value of free energy for the adsorption of EA molecule decreased with increasing number of double bonds.

* 本報告は Colloid Polym. Sci., 271，512-518（1993）に発表。

** 東京コロイド科学研究所 